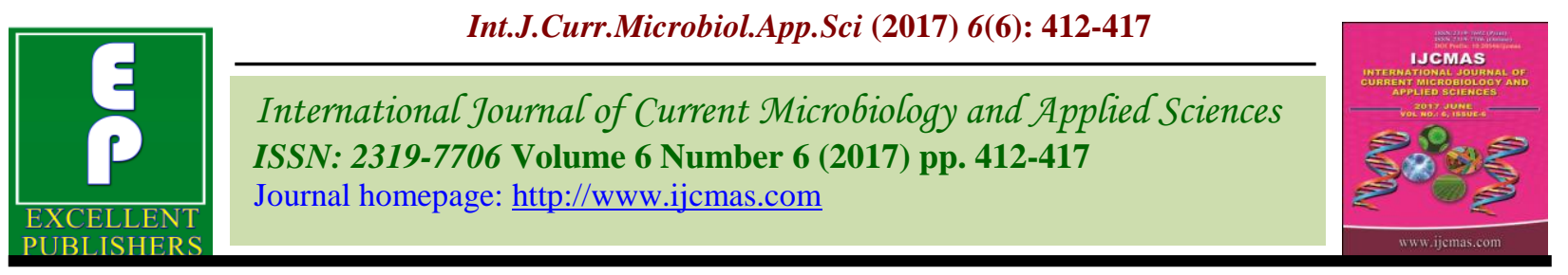

Original Research Article

https://doi.org/10.20546/ijcmas.2017.606.048

\title{
Evaluation of in- vitro Efficacy of Different Plant Extracts against Phytophthora infestans (Mont.) de Bary
}

\author{
Devesh Nagar*, S. K. Biswas, Morajdhwaj Singh and Jaskaran Singh \\ Department of Plant Pathology, Chandra Shekhar Azad University of Agriculture and \\ Technology, Kanpur, Uttar Pradesh, India \\ *Corresponding author
}

\section{A B S T R A C T}

\section{Keywords}

Plant extracts, Antifungal activity, In-vitro efficacy,

Poisoned food technique

Article Info

Accepted:

04 May 2017

Available Online:

10 June 2017
Now these days, Plant extracts are used to control plant diseases because of their eco-friendly nature and cost effectiveness. The present investigation focuses on the antifungal activity of eight plant extracts determined through in vitro following poisoned food technique. Maximum inhibition of $P$. infestans was obtained by Salix sp. leaf extract $(59.80 \%$ reduction) followed by Datura $(48.47 \%)$. The other tested plant extracts exhibited moderate activity.

\section{Introduction}

Potato is the world's fourth-largest food crop, following maize, wheat and rice and considered as "King of vegetables". Potatoes are rich source of carbohydrates, vitamins and minerals and are used as staple food in many countries, especially in England. The worldwide production of potatoes in 2010 was about 324 million tonnes (F.A.O 2011) whereas in India, production was 453.44 lakh tonnes of potato from 1922.2 ha. Of land which is 21.6 percent of total area under vegetables. Uttar Pradesh is the highest potato producing state in India with a production of 1389.94 tonnes which contribute $31.01 \%$ in total potato production of the country. Though the state ranked first in potato production in India but at per concerned on productivity, the state is far behind those other countries like
Europe and America. The main reasons of low productivity are diseases like, early blight, late blight, leaf spot, dry rot, charcoal rot, black scurf, common scab, soft rot, leaf roll etc. Among them, late blight caused by (Phytophthora infestans) (Mont.) de- Bary is most destructive disease that had led to most un-famous catastrophe in Ireland (England) during 1840-1845.

The management of the disease can be done through host resistance, cultural adjustments, biological and use of fungicides and there is no doubt that use of fungicides is the best strategy for management strategy for management of plant diseases. But most of the conventional chemicals, biological agents and use of resistance varieties tend towards 
the direct control of the pathogens by their elimination. Sometimes these practices raise problem due to development of resistant strains of the pathogen which may become very difficult to control. Beside this, elevated temperature and $\mathrm{CO}_{2}$ concentration due climate change are also posing higher threat for management of several diseases of different crops (Gautam et al., 2013). Changing disease scenario due to climate change has highlighted the need of new strategies for sustainable food production. Plant extracts have been used as alternative products in sustainable agriculture. Extracts of higher plants have demonstrated a wide range of activity against plant pathogens. (Enyiukwu et al., 2014) These plants extracts have also been found to contain broad spectra of phytochemicals (secondary metabolites) such as alkaloids, flavonoids, tannins, saponins, phenols, glycosides, terpenoids, phlobatannins, polyphenols and steroids (M.S. Gurjar et al., 2012). The presence of antifungal compounds in higher plants has long been recognized as an important factor for disease control (Mahadevan, 1982). Such compounds being biodegradable and selective in their toxicity are considerable valuable for controlling plant diseases (Singh and Diwedi, 1987).

The pesticidal compounds of plant origin are most effective and have little or no side effects in human beings in comparison to synthetic compounds (Kumar et al., 1995). The natural compounds provide less phytotoxic, more systemic and easily biodegradable fungitoxic compounds (Saxena et al., 2005).

In this study, 8 plant extracts with antifungal properties against $P$. infestans were tested under laboratory conditions to determine the effect of these extracts on mycealial growth of the fungus.

\section{Materials and Methods}

\section{Collection of plant materials}

The commonly available plants like Salix sp., Achyranthus aspera, Solanum nigrum, Parthenium hysterophorus, Datura stramonium, Melilotus alba and Convolvulus arvensis were collected from Students Research Farm Chandra Shekhar Azad University of Agriculture and Technology, Kanpur. The extracts of these plants were used to evaluate antifungal activity.

\section{Preparation of plant extracts}

The fresh and mature leaves of the common plants viz. Salix sp., Achyranthus aspera, Solanum nigrum, Parthenium hysterophorus, Datura stramonium, Melilotis alba, Lantana camara and Achyranthus aspera, were selected for preparation of plant extracts. The collected leaves were thoroughly washed under running clean tap water to remove dust and other foreign matter from the leaf surface. The extract was obtained from individual plant material by electric mixie in distilled water 1:5 (w/v). The resultant slurry was strained through a double layered muslin cloth to remove the uncrushed fibrous tissue of plant material. The procedure repeated twice and each time, the resultant slurry was filtered through two fold muslin cloth. The extract was then diluted by mixing with water at 10 percent concentration.

\section{Antifungal activity of plant extracts}

Anti fungal activity of plant extracts was determined by Poison food technique (Kumar and Tyagi, 2013; Mohanta and Raveesha, 2007). The prepared plant extracts were poured in conical flask containing tomato extract media in 1:5 (v/v) ratios. The poisoned media was later autoclaved at 15 psi and $121.6^{\circ} \mathrm{C}$ temperature for 20 minutes. 


\section{Inoculation of pathogen}

The autoclaved media containing plant extracts was poured in sterile Petri plates under aseptic conditions. After solidification of media $10 \mathrm{~mm}$ diameter mycelia discs cut from periphery of actively growing pure culture of the pathogen ( $P$. infestans), was placed at the centre of each Petri plate. Three replications were maintained for each treatment and tomato extract media without any treatment served as control. Petri plates were incubated at $28^{\circ} \mathrm{C}$ and mycelia growth was measured at every $24 \mathrm{hrs}$ interval upto 7 days

\section{In-vitro evaluation of plant extracts on radial growth of fungal colony}

Two replicates of $5-\mu \mathrm{L}$ aliquots of the plant extracts were placed $90^{\circ}$ apart on the perimeter of each of two Petri dishes each (9 $\mathrm{cm}$ in diameter) of tomato extract media. Petri dishes were incubated overnight at room temperature. A 5-mm plug of P. infestans was transferred to the center of each tomato extract medium Petri dish. The Petri dishes were incubated at $20^{\circ} \mathrm{C}$ and duplicate diameters of fungal colonies were measured at $90^{\circ}$ with a ruler when the control colony reached full growth $(85 \mathrm{~mm})$. This occurred 7 days after incubation on tomato extract media.

\section{Results and Discussion}

\section{Effect of plant extracts on mycelial growth of Phytophthora infestans in vitro}

The results of in vitro antifungal activity of 26 plant extracts are summarized in table 1 . The extracts produced different levels of antifungal activity against $P$. infestans. Results indicated that all the extracts significantly reduced the radial growth of $P$. infestans, in comparison with the control. The highest inhibition of mycelial growth of $P$. infestans was observed with Salix sp. extract (59.80\% reduction) (Fig. 1) (Farag Hanna et al., 2011) followed by Datura stramonium (48.47\%), According to Jalender and Gachande (2012) the leaf extract of $D$. stramonium and D. innoxia at $20 \%$ concentration was found more inhibitory activity against $F$. oxysporum udum, while the extract of D. stramonium at $20 \%$ concentration was inhibitory against $A$. solani. Shrestha and Tiwari (2009) reported complete inhibition of mycelial growth of Fusarium solani (Mart.) Sacc. causing dry potato tuber rot when treated with Allium sativum extract.

Table.1 Effect of plant extracts on the mycelial growth of Phytophtora infestans

\begin{tabular}{|l|c|c|}
\hline Treatment & Colony diameter $\mathbf{( m m )}$ & \% reduction against control \\
\hline Salix sp. & 40.80 & 59.80 \\
\hline Achyranthus aspera & 81.00 & 20.20 \\
\hline Solanum nigrum & 80.90 & 20.30 \\
\hline Parthenium hysterophorus & 81.00 & 20.20 \\
\hline Datura stramonium & 52.30 & 48.47 \\
\hline Melilotus albus & 81.30 & 19.90 \\
\hline Convolvulus arvensis & 80.60 & 20.59 \\
\hline Lantana camara & 80.90 & 20.30 \\
\hline Control & 90.00 & \\
\hline S.E. & 1.3606 & - \\
\hline C.D. $(\mathrm{P}=0.05)$ & 2.8594 & - \\
\hline
\end{tabular}


Table.2 Antifungal compounds in plant extracts

\begin{tabular}{|l|l|l|l|}
\hline S. No. & Common Name & Botanical Name & $\begin{array}{l}\text { Antifungal } \\
\text { compounds }\end{array}$ \\
\hline 1. & Willow & Salix sp. & Salicin \\
\hline 2. & Prickly Chaff Flower & Achyranthes aspera & $\begin{array}{l}\text { Tannins,Saponins and } \\
\text { flavonoids }\end{array}$ \\
\hline 3. & Black Nightshade & Solanum nigrum & Degalactotigonin \\
\hline 4. & Fever few or Congress Grass & $\begin{array}{l}\text { Parthenium } \\
\text { hysterophorus }\end{array}$ & Flavonoids \\
\hline 5. & Jimson Weed or Datura & Datura stramonium & Hygrine, Tropinone \\
\hline 6. & Sweet Clover & Melilotus albus & Caumarins, Saponins \\
\hline 7. & Field Bind weed or Hiran khuri & Convolvulus arvensis & $\begin{array}{l}\text { Chaffic acid and p- } \\
\text { caumaric acid }\end{array}$ \\
\hline 8. & Wild Type Spanish Flag & Lantana camara & $\begin{array}{l}\text { Sesquiterpines mainly, } \\
\text { B-caryophyllene, } \\
\text { zingiberene, -humulene, } \\
\text { arcurcumene, } \\
\text { gemacrene-D and } \\
\text { bisabolene }\end{array}$ \\
\hline
\end{tabular}

Fig.-1: Effect of plant extracts on the mycelial growth of Phytophtora infestans

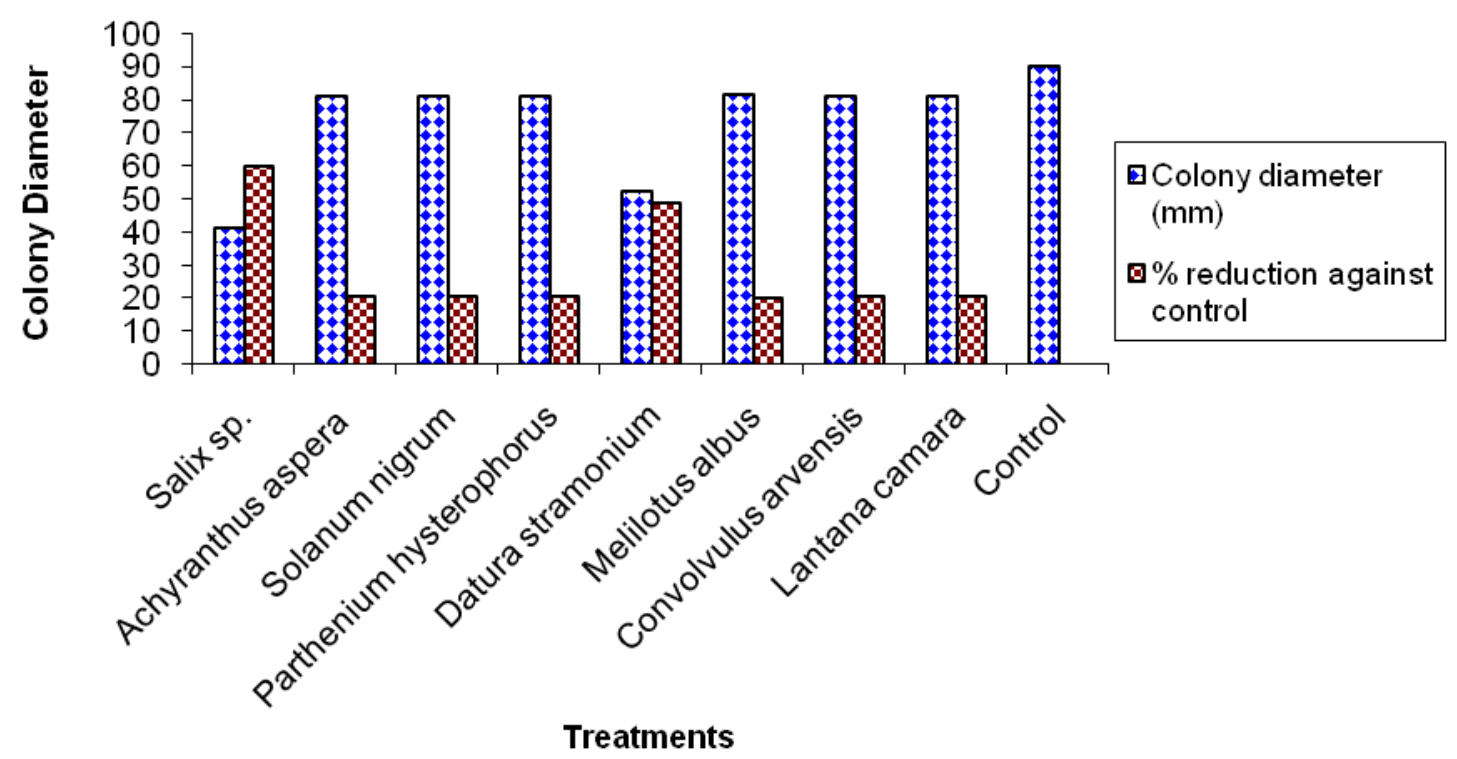


The inhibitory effect of Salix sp. (willow) aqueous extract against Phytophthora infestans could be explained by the presence of salicin i.e. glucoside of salicyl alchohol. Salicin may bind with receptors on the surface of pathogen cells and penetrates to the fungal cells which could be killed through denaturation of some enzymes and proteins. Salicin may be the major compound that shows the antifungal effect but other metabolites may increase the potency of the Salix sp. (willow) extracts compared with pure salicin (El-Shemy et al., 2007) (Table 2). Pal and Kumar (2013) also reported in-vitro mycelia inhibition of Fusarium with Achyranthes aspera and Parthenium hysterophorus extracts.

\section{References}

Arzoo Kahkashan and Biswas S.K., 2013. Effect of Plant Extracts as Seed treatments on Growth Parameters, Seedlings Mortality and Biochemical Changes in Tomato. International Journal of Bio-resource and Stress Management. 4(1): 47-53.

Cao K. Q. and Forrer H. R., 2001. Current status and prosperity on biological control of potato late blight (Phytophthora infestance). Journal of Agricultural University of Heibi. 24: 51-58

El-Shemy, H.A., Aboul-Enein, A.M., AboulEnein, K.M., Fujita, K., 2007. Willow Leaves' Extracts Contain Anti-Tumor Agents Effective against Three Cell Types. PLoS ONE 2 (1), e178.

Enyiukwu D. N., Awurum A. N., Ononuju C. C. and Nwaneri J. A., 2014. Significance of characterization of secondary metabolites from extracts of higher plants in plant disease management. International Journal of Advanced Agricultural Research. 8 (28): 2053-1265.
Ganie, S.A., Gahani, M.Y., Nissar Qazi and Shabir- Ur- Rehman., 2013. Bioefficacy of plant extracts and biocontrol agents against Alternaria solani. African Journal of Microbiology Research. 34: 4397-4402.

Gurjar, M.K., Shahid Ali, Masood Akhtar, Kangabam Suraj Singh (2012). Efficacy of plant extracts in plant disease management. Agricultural Sciences. 3: 425-433.

Hanna Farag R.M., Abdou Zeinab A., Salama Dalawat A., Ibrahim Mervat A.R., Sror H.A.M., 2011. Effect of neem and willow aqueous extracts on Fusarium wilt disease in tomato seedlings: Induction of antioxidant defensive enzymes. Annals of Agricultural Science. 56: 1-7.

Jalander V, Gachande, B.D., 2012. Effect of Aqueous Leaf Extracts of Datura sp. Against Two Plant Pathogenic Fungi. International Journal of Food, Agriculture and Veterinary Sciences. ISSN: 2277-209X.

Kavitha, H.U. and Satish, S., 2011. Ecofriendly management of plant pathogens by some medicinal plant extracts. Journal of Agricultural Technology. 7(2): 449-461.

Khan M, Srivastava SK, Shyamsundar KV, Singh M, Naqvi AA (2002) Chemical composition of leaf and flower oil of Lantana camara from India. Flavour and Fragrance Journal 17: 75-77.

Lin Tsung-Chun, Mi-Chen Fan, Sheng-Yang Wang and Jenn-Wen Huang.(2011). Identification of the Solanum nigrum Extract Component Involved in Controlling Cabbage Black Leaf Spot Disease. J. Agric. Food Chem. 59: 1667-1672

Maharajan, B.L., Shrestha, K. and Bansyat, S (2010). Botanical control of late blight of potato. Nepal Journal of Science and Technology 11: 37-40. 
Maharajan, B.L., Shrestha, K., Bansyat, S. (2010). Botanical Control of Late Blight of Potato. Nepal Journal of Science and Technology 11: 37-40.

Mohanta, D.C. and Raveesha, K.A. (2007). Antifungal evaluation of some plant extracts against some plant pathogenic field and storage fungi. Journal of Agricultural Technology 4(1): 119-137.

Nagassoum MB, Yonkeu S, Jirovetz L, Buchbauer G, Schmaus G, Hammerschmidt FJ (1999) Chemical composition of essential oils of Lantana camara leaves and flowers from Cameroon and Madagascar. Flavour and Fragrance Journal 14: 245-250.

Pal Gaurav kumar and Kumar Brijesh (2013) Antifungal activity of some common weed extracts against wilt causing fungi, Fusarium oxysporum. Current Discovery 2: (1) 62-67

Reynolds JEF, Martindale, (1996). "The Extra Pharmacopoeia", 31st edition London, Royal Pharmaceutical Society of Great Britian.

Roy, B., Sarker, B. C., Ali, M.R., Das, S.R. and Sayed M.A.S. (2012). Seed Germination and Seedling Growth of Two Vegetables in Responses to Aqueous Extract of Four Herbal Plant Leaves. J. Environ. Sci. Natural Resources 5(1): 141-150.
Shreshtha Kazi Asha and Tiwari R.D., (2009). Antifungal Activity of Crude Extracts of Some Medicinal Plants against Fusarium solani (mart.) Sacc. ECOPRINT 16: 75-78, 2009.

Singh G, Pandey SK, Leclerq PA, Sperkova J (2002) Chemical constituents of the leaf oil of Lantana indica Roxb. From north India. Journal of Essential Oil Research 14: 346-347.

Singh G, Srivastava P, Narayanan CS, Padmakumari KP (1991) Chemical investigation of the essential oil of Lantana camara. Indian Perfumer 35: 209-211.

Yusuf Yanar, Izzet Kadioğlu, Ayhan Gökçe1, Đbrahim Demirtas, Nezhun Gören, Halit Çam and Mark Whalon. (2011). In vitro antifungal activities of 26 plant extracts on mycelial growth of Phytophthora infestans (Mont.) de Bary. African Journal of Biotechnology Vol. 10 (14): 2625-2629.

Farag Hanaa R.M., Abdou Zeinab A., Salama Dawlat A., Ibrahim Mervat A.R., Sror H.A.M. (2011). Effect of neem and willow aqueous extracts on Fusarium wilt disease in tomato seedlings: Induction of antioxidant defensive enzymes. Annals of Agricultural Science (56): 1-7.

\section{How to cite this article:}

Devesh Nagar, S. K. Biswas, Morajdhwaj Singh and Jaskaran Singh. 2017. Evaluation of invitro Efficacy of Different Plant Extracts against Phytophthora infestans (Mont.) de Bary. Int.J.Curr.Microbiol.App.Sci. 6(6): 412-417. doi: https://doi.org/10.20546/ijcmas.2017.606.048 